\title{
Anticompetitive Patent Settlements \\ - Where Are We Ten Years After the European Commission's Pharmaceutical Inquiry?
}

\author{
by
}

Anna Laszczyk

\section{CONTENTS}

I. Introduction

II. Patent settlements in the Final Report

1. Patent settlements - introduction

2. Classification of patent eettlements by the Commission

3. Critical remarks

III. The EU case law on patent settlements

1. Lundbeck case

1.1. Factual background

1.2. Assessment by the Commission

1.3. The General Court's judgment in the Lundbeck case

1.4. Critical remarks

2. Fentanyl case

2.1. Factual background

2.2. Assessment by the Commission

2.3. Critical remarks

3. Perindopril case

3.1. Factual background

* Anna Laszczyk, PhD, senior associate at Linklaters C. Wiśniewski i Wspólnicy sp. k.; e-mail: anialaszczyk@gmail.com; ORCID: 0000-0003-4958-7773. This publication is based on one of the chapters of the PhD dissertation 'Patent Settlements in the Pharmaceutical Sector as Agreements Restricting Competition - Law and Economics Analysis' defended in May 2019 at the Faculty of Law and Administration of the University of Łódź. The views and the opinions expressed in this article are those of the author.

Article received: 12 July 2019, accepted: 30 October 2019. 
3.2. Assessment by the Commission

3.3. The General Court's judgments in the Perindopril case

3.4. Critical remarks

4. Teva case

5. Summary and Concluding Critical Remarks

5.1. Summary of the Commission's Test for the Assessment of PFD Agreements

5.2. PFD Agreements as a by Object Restriction - Critical Review

5.3. PFD Agreements as an Effects Restriction - Critical Review

5.4. PFD Agreements - Enforcement by National Competition Authorities

5.5. PFD Agreements - Further Developments?

\section{Abstract}

In 2009, the European Commission published a final report on its market inquiry into the pharmaceutical sector. The report revealed the authority's concerns regarding market practices of pharmaceutical originator companies aimed at delaying the market entry of cheaper generic pharmaceutical products. One of the delaying practices identified by the European Commission were patent settlements between an originator and a generic company including: (i) a value transfer from the originator to a generic company, and (ii) an obligation of a generic company not to enter the market. These patent settlements were called pay-for-delay agreements since the payment was allegedly made in exchange for the non-marketentry obligation. The European Commission continued the investigation of patent settlements by its continuous monitoring. It also initiated antitrust proceedings that terminated with huge fines imposed on pharmaceutical companies. The appeals are now pending before the EU courts. Ten years after the publication of the final report on the market inquiry, this article aims to summarise the development of the case law and provide its critical analysis. The article focuses on the analysis of pay-for-delay agreements as infringements of Article 101 TFEU only and does not consider the conclusion of these agreements as an abuse of a dominant position.

\section{Résumé}

En 2009, la Commission européenne a publié un rapport final sur son enquête de marché concernant le secteur pharmaceutique. Le rapport a révélé les préoccupations de la Commission concernant les pratiques de marché des laboratoires pharmaceutiques visant à retarder l'entrée sur le marché de produits pharmaceutiques génériques moins chers. Lune des pratiques retardatrices identifiées par la Commission européenne était les règlements de brevet entre un laboratoire et un fabricant de produits génériques, notamment : (i) un transfert de valeur du laboratoire de vers un fabricant de génériques, et (ii) l'obligation pour un fabricant de génériques de ne pas entrer sur le marché. Ces accords de brevet étaient qualifiés 
d'accords de paiement pour retard, puisque le paiement était apparemment effectué en échange de l'obligation de ne pas entrer sur le marché. La Commission européenne a poursuivi l'enquête sur les accords de brevet en exerçant une surveillance continue. Elle a également lancé des procédures antitrust qui se sont terminées par l'imposition d'amendes considérables aux sociétés pharmaceutiques. Les recours sont maintenant en cours devant les tribunaux de l'UE. Dix ans après la publication du rapport final sur l'enquête de marché, cet article vise à résumer l'évolution de la jurisprudence et à fournir une analyse critique. Larticle se concentre sur l'analyse des accords de paiement des retards en tant qu'infractions à l'article 101 du TFUE uniquement et ne considère pas la conclusion de ces accords comme un abus de position dominante.

Key words: antitrust law; anticompetitive agreements; patent settlements; pay-fordelay agreements; pharmaceutical sector.

JEL: K21

\section{Introduction}

In 2009, the European Commission (the Commission) published the final report on its market inquiry into the pharmaceutical sector, in which it identified practices of originator companies aimed at delaying the market entry of generic companies (hereinafter: the Final Report). ${ }^{1}$

According to the Commission, patent settlements concluded between an originator and a generic company are an example of delaying practices. Patent settlements are agreements aimed at terminating a patent dispute stemming either from invalidation claims raised by a generic company against the patents held by the originator company, or from an alleged patent infringement by a generic company.

In principle, settlements are a legitimate means for ending a patent dispute, which also benefits the public interest by reducing litigation costs (Szczepanowska-Kozłowska, 2015, p. 473). Generally, most patent disputes are settled, however, the rate of settlement is lower than in other types of litigation (Bucknell, 2011, p. 114). However, there may be instances when settlements include: (i) a restriction on generic companies' market entry and a (ii) value transfer from the originator company to a generic company. This value transfer usually (but not always) takes the form of a payment of a lump sum of money (a reverse payment). Settlements in which an originator company pays a generic company for not entering the market are commonly named pay-for-delay

1 The Final Report by the European Commission on the Pharmaceutical Sector Inquiry dated 8 July 2009. 
(PFD) agreements or reverse payment settlements. ${ }^{2}$ In the Final Report, the Commission expressed its interest in further investigating PFD agreements.

It has been ten years since the publication of the Final Report. During that time the Commission continued to monitor patent settlements as well as pursued four cases on PFD agreements. Three of them already terminated with sanctioning decisions and the proceedings before the EU courts are pending; one of the proceedings is still on-going.

Despite yearly monitoring by the Commission and its decisional practice regarding PFD agreements, some topics in this area are still unsettled. Generally, there is a common agreement among scholars that under certain circumstances PFD agreements may restrict competition (Choi et al., 2014, p. 44-52). However, they have diverging views on these circumstances determining a competition law infringement. ${ }^{3}$ Yearly reports from monitoring conducted by the Commission did not provide much clarity of the competitive assessment of PFD agreements. The test applied by the authority in its sanctioning decisions raises doubts as to the compatibility with the main principles of competition law (Subiotto, Diaz, 2017, p. 27-29). In fact, views of the Court of Justice of the European Union (hereinafter: CJEU) are much awaited. The aim of this article is to critically review the monitoring exercise of patent settlements by the Commission and its case law.

The article focuses on the analysis of pay-for-delay agreements as an infringement of Article 101 TFEU only, and does not consider them as an infringement of Article 102 TFEU. The main reason is that PFD agreements did not amount to an abuse of a dominant position as such, but only as part of exclusionary strategies which constituted an infringement of Article 102 TFEU. An exhaustive analysis of PFD agreements as a breach of both TFEU's

${ }^{2}$ However, some scholars criticised linking the payment with the restrictive character of settlement. Marc van der Woude argued that payments may be included in all sorts of arrangements - restrictive and not restrictive to competition - therefore they should not play a key role in the antitrust assessment. He claimed that the review of PFD agreements requires an analysis of the patent strength, which is a technical issue, therefore the presence of the payment is not relevant for this assessment. For the sake of completeness, it should be added that he also notes that in certain scenarios, a large and unexplained payment may offer circumstantial evidence for finding a competition law infringement. However, he does not suggest that the payment should be a key indicator of the anti-competitive potential of PFD agreements. (Woude, 2009, 183-196). See also Regibeau, 2013.

${ }^{3}$ Some claim that the large and unexplained value transfer is sufficient to determine the anti-competitive potential of the settlement (Kolasiński, 2017). Others consider that PGD agreements should not be qualified as a by object restriction - (Ska, Werner, Paul, 2017), (Friend, 2017), (Hull, Clancy, 2017), (Barazza, 2014), (Schröder, 2016), (Murphy, 2008), (Straus, 2016), (Geradin, Ginsburg, Safty, 2015), (Gratz, 2012). Some, inspired by the concept of the quick rule of reason in U.S. antitrust law, suggested an application of a structured effects-based analysis (Gallasch, 2016). 
provisions would require a thorough examination of the applied exclusionary strategy (as an actual infringement) and therefore would not be possible within the scope of this paper.

\section{Patent settlements in the Final Report}

\section{Patent Settlements - introduction}

Patent settlements are agreements between a patent holder and a third party aimed at ending amicably the following: (i) an on-going or a potential patent dispute, (ii) opposition proceedings or (iii) on-going court proceedings. Thus, a patent settlement may be concluded at any time of a dispute, that is, either before a claim has been filed with a court or at any stage of the court proceedings. Patent disputes usually concern either infringement or invalidation claims.

The main reasons for settling patent disputes is the parties' willingness to avoid considerable costs and commercial uncertainty. The courts also tend to encourage settlements since they contribute to procedural efficiency and free the courts up to devote its resources to other matters. In the case of parallel patent litigation, a patent holder may be willing to settle with a view to avoiding diverging rulings in various jurisdictions. As regards patent settlements in the pharmaceutical sector, it was argued that a large number of invalidated patents motivates originator companies to enter into PFD agreements to protect their, allegedly, weak patents (Kerber, Frank, 2016, p. 4).

Patent settlements usually encompass the following provisions: considerations on the litigation withdrawal, a no-challenge clause or an obligation to recognise the validity of the patent, an obligation to cease infringement, a possible term of the early entry of a generic company (if applicable) and possible terms of the licence (Treacy, Lawrance, 2011, 281). A licence agreement may also be concluded separately but may still remain related to the patent settlement.

\section{Classification of the Patent Settlements by the Commission}

In the Final Report, the Commission distinguished between settlements which do not limit a generic entry (type A) and settlements limiting a generic entry (type B). ${ }^{4}$ The most straightforward limitation is to oblige a generic

\footnotetext{
${ }^{4}$ Final Report, paras 741-742.
} 
company to recognise the validity of a patent and to refrain from entering the market. Other examples include a no-challenge clause, granting of a patent licence, appointment of a generic company as a distributor or appointment of an innovative company as an exclusive supplier.

The Commission categorises type B settlements into two groups: B.I. settlements which do not comprise a value transfer and B.II settlements which comprise a value transfer. The value transfer could be (but not always) a payment made by an originator company to a generic one. The rationale for a payment may be the return of costs borne by generic companies with regard to patent disputes, purchase of generic companies' assets or fees for stock services rendered by a generic company. Furthermore, the risk of the invalidation of a patent may incentivise originator companies to enter into PFD agreements (Kerber, Frank, 2016).

In the Final Report, the Commission found that in the period between 2000 and 2007, 108 out of 207 settlements did not include limitations on generic companies' market entry. ${ }^{5}$ The majority of them was concluded either shortly after or shortly before the patent's expiration. 99 of the analysed settlements were of type B and approximately half of them (44) included a value transfer in the form of a lump sum of money paid directly to a generic company, agreements on distribution of pharmaceuticals or supply of an active substance as well as licences arrangements. ${ }^{6}$

Since 2010, the Commission has been conducting yearly monitoring of patent settlements. The last report for the year 2016 was issued in March $2018 .^{7}$ The number of B.II settlements decreased significantly from 2002 until 2010. At the same time, since 2011 the share of B.II settlements in the total number of settlements has amounted to approximately $10 \%$ with certain variations (that is, below 10\% in 2012 and 2013 and above 10\% in 2011 and 2014).

In the Final Report, the Commission pointed out that B.II settlements have the potential of limiting market entry of generic companies and, as a result, harm consumers who will be deprived of access to cheaper pharmaceuticals. ${ }^{8}$ The Commission is most likely to scrutinise clauses obligating an originator company to pay a lump sum of money, imposing limitations on generic companies exceeding the scope of the patent (as, for instance, the patent validity period, the subject of patent protection or the geographic area of

5 Final Report, para 746.

${ }^{6}$ Final Report, para 758.

7 European Commission, ' 8 th Report on the Monitoring of Patent Settlements (period: January-December 2016),' 9 March 2018. Retrived from: http://ec.europa.eu/competition/ sectors/pharmaceuticals/inquiry/patent_settlements_report8_en.pdf.

8 Final Report, paras. 769-770. 
protection). The Commission is of the opinion that this type of clause is not directly related to patent rights. The Commission is also expected to review settlements concluded in a situation when a patent holder should know that their invention did not meet the patentability criteria, that is, for example a situation when a patent is granted on the basis of false or misleading information provided by an undertaking.

\section{Critical Remarks}

The effects of the monitoring exercise conducted by the Commission do not appear to be material (Hull, Clancy, 2018, p. 389-402).

As explained in the introduction to the most recent report: 'The main objectives of the monitoring exercise are to better understand the use of this type of agreement in the EEA and identify those settlements that delay generic market entry to the detriment of the European consumer possibly in violation of European competition law'. ${ }^{9}$

However, the conclusions of the reports are limited to presenting statistics on the number of concluded settlements and explaining that the monitoring exercise did not negatively impact companies' incentives to enter into settlements.

Regrettably, the Commission did not meet its objective of a better understanding of patent settlements, since it still has not come up with guidance that would be more detailed than the distinction made in the course of the Final Report. The Commission seems to ignore that by its very nature a settlement 'must restrain competition in order to be mutually-acceptable' (Hovenkamp, 2018, p. 11).

Further, it remains relatively vague by stating that a pure early entry agreement is "not likely to attract the highest degree of antitrust scrutiny, or that list of possible value transfers is not exhaustive and that B.II settlements are likely to attract the highest degree of antitrust scrutiny, but they need to be assessed on the basis of circumstances of each individual case'.10

On the one hand, statements made by the Commission may be read as a reassurance that no settlement is presumably illegal. However, on the other hand, a loose language and a promise of a case-by-case analysis, without specifying concrete conditions, may undermine legal certainty.

The Commission seemed to fail also with fulfilling the second objective namely the identification of potentially harmful settlements. Currently, there is

9 European Commission, ' 8 th Report on the Monitoring of Patent Settlements (period: January-December 2016)’, p. 1.

10 Ibidem, p. 4. 
no publicly available information about any new proceedings instigated against pharmaceutical companies in relation to allegedly anticompetitive settlements. Thus, the only cases pursued by the Commission are those initiated at the time of the pharmaceutical inquiry. Given that the share of potentially problematic settlements has remained relatively stable, the absence of a Commission intervention may raise doubts as to the accuracy of the assessment made in the Lundbeck ${ }^{11}$ and Perindopril ${ }^{12}$ cases.

In its analysis, the Commission, by focusing on static price competition only, seems to ignore the economic complexity of the potential effects of patent settlements. This emphasis is to a certain extent justified. Some economic analyses confirm that in the event of a patent dispute, a choice of a PFD agreement (instead of litigation) may make consumers worse off due to the later entry of the generic products (Shapiro, 2003; Elhauge and Krüger, 2012). However, examining PFD agreements under more realistic assumptions, among other things concerning the particularities of negotiations (e.g. information asymmetry, risk aversion), show that the above conclusions are less obvious.

In particular, besides static competition, PFD agreements may be considered within the realm of dynamic competition. An antitrust ban on PFD agreements limits the possibilities of the originator companies to protect their patents and, therefore, may negatively influence their incentives to innovate. As a consequence, consumers may be worse off in the long-term since they would not get access to novel pharmaceuticals. Thus, a potentially pro-competitive justification of PFD agreements could be innovation incentive effects. So far, they have not been exhaustively analysed in the literature. Yet existing scant analyses reveal that innovation incentive effects do not prevail over harm to price competition.

Elhauge and Krüger researched whether settlements harm ex ante welfare, by exceeding the optimal patent exclusion period and thus optimal reward for innovation (Elhauge, Krüger, 2012). They conclude that all settlements with reverse payments should be presumably illegal (with few rebuttals only). At the same time, they consider that even settlements without reverse payments may be anti-competitive. Woodcock analyses whether a ban on patent settlements decreases originators incentives to innovation. He reaches the conclusion that gains from innovation activities do not outweigh harm resulting from the delayed entry of generic companies (Woodcock, 2017).

More research is needed in this area to ultimately confirm the absence or presence of innovation incentive effects. Further it would be interesting to learn

11 Decision of the European Commission in Lundbeck (Case AT.39226) [2013] OJ C368/13.

12 Decision of the European Commission in Perindopril (Servier) (Case AT 39612) [2014] OJ 2016 C 393/7. 
whether potential R\&D activities undertaken by originator companies would concern truly novel pharmaceuticals or would amount to just incremental innovation. In any case, difficulties in assessment of PFD agreements on dynamic competition should not prevent the Commission from considering these possible justifications.

The Commission also seems to ignore potential chilling effect of an antitrust ban on PFD agreements when it comes to generic companies' incentives to challenge weak patents (Kerber, Frank, 2016).

The above shows that PFD agreements have complex effects on various dimensions of competition. Therefore, their analysis from the static competition perspective and in the short term only, cannot be deemed as enough. Potential negative effects to price competition should be compared to potential negative effects to dynamic competition including absence of incentives to engage in $\mathrm{R} \& \mathrm{D}$ activities and to challenge weak patents.

\section{The EU case law on patent settlements}

\section{Lundbeck case}

\subsection{Factual background}

The Lundbeck case was the first decision finding patent settlements as restricting competition. The decision concerned 6 agreements concluded between a Danish originator company - Lundbeck - and four generic companies, namely, Merck KGa, Alpharma, Arrow, and Ranbaxy. The agreements related to an antidepressant containing an API developed by Lundbeck (citalopram), which was a blockbuster manufactured, patented and marketed by this originator company. Lundbeck obtained patent protection not only for the product itself but also for several processes of manufacturing citalopram.

The Commission established that, very early before patent expiration, Lundbeck started preparing for a market entry of generic companies and perceived them as a competitive threat. The Commission found Lundbeck's internal documents setting out its strategy aimed at minimising negative effects of such entry.

One of the elements of this strategy was entering into agreements with generic companies aimed at delaying or preventing their market entry. Lundbeck concluded 6 patent settlements with Merck, Arrow, Alpharma, and Ranbaxy on the basis of which it transferred to them approximately 
EUR 67 million. All settlements were concluded in the context of a patent dispute before any litigation had started (except for the settlement with Alpharma). Thus, at the time when the parties settled there was no court ruling, even by way of interim measures.

\subsection{Assessment by the Commission}

The Commission found that settlements concluded by Lundbeck with 4 generic companies had as their object the restriction of competition. The Commission based its reasoning on the following findings: ${ }^{13}$ (i) Lundbeck and the generic companies were at least potential competitors at the time of concluding the settlements; (ii) Lundbeck transferred to the generic companies a lump sum of money that reflected expected revenues from marketing a generic citalopram; (iii) the mentioned value transfer was linked to generics' commitment to desist from individual actions aimed at introducing a generic citalopram to the market; (iv) Lundbeck could not have obtained these limitations through enforcement of its process patents as the generics' obligations went beyond the scope of the patent; (v) settlements did not contain Lundbeck's commitment to refrain from bringing infringement proceedings against generic companies if the latter entered the market with a generic citalopram after the expiration of the agreements.

In the view of the Commission, a patent settlement concluded: (i) without any additional inducement, (ii) on the basis of assessment of the strength of the patent, (iii) with restrictions falling within the scope of patent law, should not raise controversies from the antitrust perspective if said conditions are met cumulatively. ${ }^{14}$ The Commission also argued that an inclusion of the value transfer does not necessarily mean that a patent settlement shall be deemed abusive. ${ }^{15}$

13 Lundbeck decision, see paras. 824 and 874 with regard to settlements concluded with Merck, paras. 962 and 1013 with regard to settlements concluded with Arrow, para. 1087 with regard to the settlement concluded with Alpharma, para. 1174 with regard to the settlement concluded with Ranbaxy.

${ }^{14}$ Lundbeck decision, paras. 638-639.

15 Lundbeck decision, para. 639. This may concern a situation when a generic company faced with threats of a patent infringement claim, decides not to enter the market and then, subsequently, the generic and innovative companies find an invalidity of a patent or noninfringement highly possible. A value transferred to a generic company from an innovative company would then encompass potential revenues that would be generated if a generic company entered the market. 


\subsection{The General Court's judgment in the Lundbeck case}

Lundbeck and the generic companies appealed against the Lundbeck decision to the General Court (hereinafter: GC). They pleaded that the Commission erroneously determined that Lundbeck and generic companies were at least potential competitors. Further, five pleas concerned in essence the error in applying Article 101 TFEU allegedly committed by the Commission. In particular, the applicants disputed the qualification of the settlements as restriction of competition by object. Lundbeck and the generic companies also challenged the Commission's assessment of efficiency gains and the way it calculated the fines.

The GC upheld the Lundbeck decision and shared the reasoning of the Commission. ${ }^{16}$ The GC revived the old-fashioned concept of the subjectmatter of the patent ${ }^{17}$, implying the Commission's right to analyse the scope of the patent when it is necessary for establishing whether Article 101 or 102 TFEU was infringed. ${ }^{18}$ It fully agreed with the Commission that Lundbeck and the generic companies were at least potential competitors.

The GC confirmed the Commission's approach that settlements concluded by Lundbeck with generic companies were comparable to market exclusion agreements which are considered as hardcore restrictions and, thus, that settlements had as their object the restrictions of competition. ${ }^{19}$ The GC approved the reasoning of the Commission based on contextual elements such as the existence of disproportionate reverse payment corresponding to generics' expected profits as well as the absence of a clause enabling them to enter the market upon the expiry of the settlements at issue and restrictions going beyond the scope of Lundbeck patents. ${ }^{20}$

When analysing the applicants' argument that the Commission erroneously rejected the scope-of-the-patent test, the GC again referred to the specific subjectmatter of the patent and underlined that it does not encompass full protection against patent challenges. ${ }^{21}$ Although a patent holder is entitled to oppose the patent infringements, he cannot exclude competitors by means of an agreement. ${ }^{22}$

16 GC judgment of 8 September 2013, Case T-472/13 H. Lundbeck A/S and Lundbeck Ltd v. European Commission, ECLI:EU:T:2016:449.

17 T-472/13 Lundbeck, para. 117.

18 T-472/13 Lundbeck, para. 119. The GC referred to the formalistic judgment in the Windsurfing case - CJEU judgment of 25 February 1986, Case 193/83 Windsurfing International Inc. v Commission, ECLI:EU:C:1986:75.

19 T-472/13 Lundbeck, para. 145.

20 T-472/13 Lundbeck, para. 500.

21 T-472/13 Lundbeck, para. 487.

22 T-472/13 Lundbeck, para. 495. 
The GC explained that the Commission correctly applied the 'by object' restriction test, instead of an unknown to the EU competition law scope-ofthe-patent test.

\subsection{Critical remarks}

Before entering into the merits of the Lundbeck case, it is worth to consider the issue of the potential competition the existence of which between the originator and the generic companies enabled the Commission to find a horizontal anti-competitive agreement. The existence of potential competition was confirmed by the GC. This approach seems to be inconsistent with past decisional practice of the Commission whereby the existence of valid patents makes potential entry at risk not sustainable and therefore at risk entrants cannot be considered as potential competitors. ${ }^{23}$ The approach adopted by the Commission and the GC in the Lundbeck case seem to view patents as probabilistic rights in a sense that a legal monopoly granted by a patent right does not exclude potential competition (Pais, 2017).

In the Lundbeck decision, the Commission applied the object restriction concept to the patent settlements agreements. Given that conducting an analysis of effects is more time-consuming and brings more difficulties, by issuing the Lundbeck decision, the Commission might have wanted to establish a precedent for next cases. Later case law proves that the reasoning developed in this case was applied not only by the Commission but also by national competition authorities (see, for instance, the decision issued by the UK Competition and Markets Authority (the CMA) in the Paroxetine case) ${ }^{24}$.

It took the Commission ten years to issue the Lundbeck decision. Thus, one may have reasonable doubts whether the object restriction concept was correctly applied in this case. In particular, if one bears in mind the fact that the decision was issued before the CJEU's judgment in the Groupement des Cartes Bancaires (CB) case. ${ }^{25}$

In principle the Commission seems to follow the approach established by the CJEU in the case law concerning object restrictions, that is, it mainly focuses on the content of the agreement and tries to analyse it in the realm of

23 In the merger case involving Teva and Cephalon, the Commission found generic companies could not be considered as potential competitors to Cephalon. The Commission explained that before patent expiration, the competitors could only launch at risk and Cephalon always took legal action in the event of generic companies' attempts to enter the market: Teva/ Cephalon (Case No COMP/M.6258) [2014] OJ C 46/02.

24 Case CE-9531/11 [2016].

25 CJEU judgment of 11 September 2014, Case C-67/13 P Groupement des Cartes Bancaires (CB) v. Commission, ECLI:EU:C:2014:2204. 
the legal and economic context surrounding its conclusion. Parties' intentions established mainly on the basis of internal documents - serve the Commission as additional factors confirming the existence of the infringement.

However, the Commission's analysis of the legal and economic context does not put sufficient weight on the existence of a patent dispute between the parties. This is further confirmed by the approach of the GC which seems to be reluctant to take into account particularities of the pharmaceutical industry, weaknesses of the patent system and importance of intellectual property rights (Subiotto, Diaz, 2017, p. 27-29).

The Commission - on the basis of the parties' internal documents and the amount of the value transfer - tries to make a patent dispute fictitious and prove that it was obvious that relevant Lundbeck patents were invalid. Caution should be applied in such reasoning since even patent experts encounter substantial difficulties in determining the validity of a patent (Zafar, 2014, 209). The presence of a patent dispute does not allow it to claim that the agreement was sufficiently deleterious to competition. Therefore, the approach suggested by the Commission does not stand the scrutiny in the light of the CJEU's judgment in the $C B$ case.

\section{Fentanyl Case}

\subsection{Factual background}

The second PFD decision issued by the Commission concerned the co-promotion agreement between subsidiaries of Johnson and Johnson (hereinafter: $\mathrm{J} \& \mathrm{~J}$ ) and Novartis. ${ }^{26}$ On the basis of the agreement, subsidiaries of Novartis obliged themselves to jointly promote J\&J's fentanyl matrix patches in the Netherlands. In consideration for these services, J\&J agreed to make monthly payments.

\subsection{Assessment by the Commission}

The agreement was labelled as a PFD agreement and the reasoning of the Commission followed the one established in the Lundbeck case. The Commission found the co-promotion agreement to restrict competition by object. As in the Lundbeck case, the Commission drew an analogy between the co-promotion agreement and the agreements analysed in the $B I D S^{27}$

26 Decision of the Commission in Fentanyl case (Case AT.39685) [2013].

27 CJEU judgment of 20 November 2008, Case C-209/07 Competition Authority v. Beef Industry Development Society Ltd. and Barry Brothers (Carrigmore) Meats Ltd., ECLI:EU:C:2008:643. 
case. ${ }^{28}$ It proposed the following test to verify the anti-competitive potential of the agreement in question, that is, (i) the potential competition between an originator and a generic company, (ii) limitation on the generic market entry, (iii) value transfer to a generic company by an originator reducing incentives of the former to enter the market. ${ }^{29}$ Other factors considered by the Commission included the fact that the value transfer exceeded what Hexal and Sandoz expected to achieve by launching a generic fentanyl. ${ }^{30}$ Moreover, the authority found that Novartis's subsidiaries carried out very limited promotion activities. $^{31}$

The Commission found that at the time when the agreement was concluded there were no regulatory obstacles, ${ }^{32}$ subsidiaries of Novartis were actively preparing the launch of their own generic fentanyl ${ }^{33}$ and that $\mathrm{J} \& \mathrm{~J}$ perceived Novartis subsidiaries as potential competitors in the Netherlands. ${ }^{34}$ These findings led the Commission to conclude that subsidiaries of respectively Novartis and $\mathbf{J} \& \mathbf{J}$ were at least potential competitors in the Netherlands at the time when the agreement was concluded.

Review of the content of the agreement raised competition concerns pertaining to the prevention of market entry of a potential competitor at the time when its entry was imminent. ${ }^{35}$ Furthermore, the payment made prima facie in consideration for promotion services appeared to be a payment for keeping the competitor out of the market. In particular, the Commission found that the agreement did not contain a detailed description of services to be provided to J\&J by Novartis' subsidiaries and the importance of such services was in fact negligible. Moreover, the payment made by $\mathrm{J} \& \mathrm{~J}$ considerably

28 The Commission pointed out that as in the BIDS case, in the co-promotion agreement 'two (potential) competitors agreed on a common plan whereby a close, or the most advanced, generic undertaking was given the incentive not to enter the market with its own generic product by a substantial payment which would lost in case of entry. The main difference is that in the case at hand, there is no question of reducing any overcapacity in the market, but rather of preserving and sharing supra-competitive profits of the incumbent undertaking and thus restricting competition between them compared to the situation that most probably would have arises in the absence of the agreement in question.' (Fentanyl Decision, para. 218).

${ }^{29}$ Fentanyl decision, para. 219.

30 Fentanyl decision, para. 220.

31 Fentanyl decision, para. 220.

32 Such as patent protection, SPC, data exclusivity, insurmountable difficulties to obtain marketing authorisation and decision on pricing and reimbursement.

33 This was corroborated by a number of internal documents and e-mail correspondence proving the ability and possibility of Novartis to launch the generic fentanyl - Fentanyl decision, see paras. 233-238.

34 This finding was based on similar evidence as indicated above - Fentanyl decision, see paras. 248-252.

35 Fentanyl decision, para. 258. 
exceeded revenues expected by Novartis' subsidiaries from launching generic fentanyl patches. ${ }^{36}$ The analysis on the content of the agreement proved that its main objective was to 'block the imminent market entry of' Novartis' subsidiaries. ${ }^{37}$

\subsection{Critical remarks}

The Fentanyl decision is usually categorised as concerning PFD agreements, similar to the Lundbeck and Perindopril cases. The most likely reason is that the Commission applied largely the same test. However, there is an important difference between all three cases. The Fentanyl case was not related to a patent dispute whereas Lundbeck and Perindopril were. The similarity of the applied test, including in relation to potential competition, proves that the Commission effectively disregards the existence of patent rights when establishing the relation of potential competition (Lawrance, Rotondo, Treacy, 2016, p. 231).

In the Fentanyl case, the test proposed by the Commission does not raise substantial concerns. Given the absence of the patent dispute, the payment in exchange of a commitment not to enter the market (even if implicit) proves the existence of an agreements whose object is to restrict competition.

It appears from the factual background that drawing similarities between Fentanyl and BIDS cases, as the Commission did, is not unfounded. In practice, the Fentanyl case may be rightly described as buying-off of the competition since services allegedly rendered by Hexal and Sandoz were not actually effectuated. Thus, the alleged co-promotion agreement was concluded solely in order to disguise the payment in exchange for no market entry.

\section{Perindopril case}

The third PFD decision issued by the Commission is of particular interest for several reasons. First, it concerns settlements that remained within the scope of the patent, secondly, the value transfers, besides reverse payments, took forms of an exclusive licence and side deals, thirdly although the Commission found competition restriction by 'object', it also analysed effects of the settlements. Finally, the Commission determined that the strategy implemented by Servier concerning patent acquisition (that included also patent settlements) constituted an abuse of its dominant position. Given the focus of this article, only the part of the decision concerning an infringement of Article 101 TFEU will be summarised.

\footnotetext{
36 Fentanyl decision, para. 322.

37 Fentanyl decision, para. 329.
} 


\subsection{Factual background}

The case concerned a strategy implemented by Servier whose objective was to protect the market position of its best-selling product namely perindopril. ${ }^{38}$ Servier was very active in monitoring possible launches of a generic perindopril and once the threat of a generic market entry was close, it was sending warning letters. ${ }^{39}$ If these proved to be unsuccessful, Servier sought for injunctions and engaged in litigation proceedings. It also concluded settlements with Niche/ Unichem, Matrix, Teva, Krka, and Lupin.

An overview of the settlements is provided below:

Table 1. Overview of Servier's settlements

\begin{tabular}{|l|c|c|c|c|c|}
\hline \multicolumn{1}{|c|}{ Competitors } & Niche/Unichem & Matrix & Teva & Krka & Lupin \\
\hline Area covered & EU & EU & UK & $\begin{array}{c}20 \text { Member } \\
\text { States }\end{array}$ & EU \\
\hline Signing date & 8.2 .2005 & 8.2 .2005 & 13.6 .2006 & 27.10 .2006 & 30.1 .2007 \\
\hline End date & $\begin{array}{c}\text { Effects ended with the annulment of the so-called 'alpha-crystalline' patent } \\
\text { (UK: 6.7.2007, NL: 12.12.2008, IT: 13.2.2009, EPO: 6.5.2009) }\end{array}$ \\
\hline $\begin{array}{l}\text { Value transfer } \\
\text { (in EUR } \\
\text { million) }\end{array}$ & 17,2 & 17,2 & 15,6 & $\begin{array}{c}\text { Grant of an } \\
\text { exclusive } \\
\text { licence } \\
\text { resulting in } \\
\text { market sharing } \\
\text { with duopoly } \\
\text { profits in 7 } \\
\text { Member States }\end{array}$ & $\begin{array}{c}\text { (as payment } \\
\text { for IPRs) }\end{array}$ \\
\hline
\end{tabular}

Source: Summary of the Servier decision ${ }^{40}$, para. 7.

\subsection{Assessment by the Commission}

The Commission used the same test as applied in the Lundbeck and Fentanyl cases, consisting of the following conditions: (i) the existence of potential competition between a generic and the originator company, (ii) whether a generic company abandoned its independent efforts to enter the market,

38 An angiotensin converting enzyme inhibitor used for treatment of cardiovascular diseases, primary intended for treatment of hypertension and heart failure.

39 Between 27 February 2006 and 7 November 2008, Servier sent 52 warning letters.

40 Summary of Commission decision of 9 July 2016 relating to a proceeding under Articles 101 and 102 of the TFEU, Case AT.39612 - Perindopril (Servier), 2016/C 393/05). 
(iii) a value transfer and whether it induced a generic company not to pursue its efforts to enter the market. ${ }^{41}$

In the Perindopril case, the Commission additionally took into account the following factors: (i) period of the restriction, namely that it concerned the entire term of a patent protection, (ii) absence of Servier's commitment to refrain from infringement proceedings in case of an independent entry after the settlement's expiration, (iii) value transfer reflecting expected generics' turnover or the profit, (iv) the fact that certain obligations of the generics exceeded the scope of patent litigation. ${ }^{42}$

As regards potential competitors, the Commission found that Servier and all generic companies with whom it entered into settlements were at least potential competitors. This finding is based on the identified ability and intention of the generic companies to enter the market as well as on a market perception of Servier and other generic companies.

The Commission found that settlements contained the two following elements: limitations on generic companies (usually in the form of nonchallenge and non-compete obligations) and a value transfer (in the form of a lump sum payment, licence, side deals or payment for prima facie acquisition of IPRs).

The Commission explained that the non-challenge clause ensured Servier that no generic would represent a competitive threat through seeking the declaration of non-infringement or possible challenges to its patents. Whereas the non-compete clause ensured Servier that no generic perindopril would be placed on the market by settling generics.

As regards the value transfer, the Commission found that Servier made payments in consideration for the above obligations of generic companies. Besides payments of a lump sum of money, the Commission identified that the licence agreement, side deals, and agreements by which Servier acquired certain IPRs constituted value transfers.

With regard to the Krka settlement, the Commission concluded that the licence granted by Servier in several countries constituted an inducement for Krka to refrain from competing with Servier elsewhere in Europe. 43 The Commission clarified that a self-standing licence should not be considered as an infringement of Article 101 of the TFEU. ${ }^{44}$ However, in the view of the Commission, the specific context of the Servier case meant that the license served as a tool for market sharing.

\footnotetext{
41 Servier decision, para. 1154.

42 Servier decision, para. 1155.

43 Servier decision, para. 1756.

44 Servier decision, para. 1745.
} 
The Commission also considered a side deal to be a value transfer. This concerned an agreement concluded between Servier's subsidiary - Biogaran and Niche. The Commission established that there was a link between the settlement and this agreement and that there are certain indications proving that it was not an arm's length deal. ${ }^{45} \mathrm{On}$ this basis, the Commission established that a side deal constituted an additional inducement to Niche to desist from bringing to the market a generic perindopril.

Servier acquired from Krka and Lupin several IPRs that, in principle, were aimed at improving the manufacture of perindopril. In fact, the Commission established that the payment made by Servier constituted further inducement for the generic companies to enter into settlements. The Commission based its conclusion, among other issues, on finding that Servier made very limited use of the acquired technologies.

All of the above findings and evaluation of Servier's and generic companies' intention led the Commission to the conclusion that the settlements had as its object the restriction of competition. The Commission also analysed the effects of the settlements. Its analysis covered the examination of (i) Servier's market position, (ii) the relation of potential competition between Servier and generic companies, (iii) the content of the agreement, and (iv) counterfactual, that is, competition that would have existed in the absence of settlements.

The Commission considered that in the absence of settlements, the generic companies would constitute a competitive threat to Servier since they had incentives to challenge the patent and to undertake actions aimed at bringing generic product to the market. ${ }^{46}$ The analysis of the Commission focuses on underlining that, in the absence of the settlement (that is, in a scenario of an early generic entry) consumer spending would be lower. The Commission also evaluated other relevant sources of competition. ${ }^{47}$ It found that besides the generic companies settling, there were no other pharmaceutical companies that might have exercised substantial competitive pressure on Servier, or that might have brought generic perindopril to the market in a reasonable period of time. Thus, the Commission concluded that the settlements had restrictive effects on competition.

\footnotetext{
45 Servier decision, para. 1351.

46 Servier decision, para. 1243.

47 Servier decision, paras. 1244-1260.
} 


\subsection{The GC's judgments in the Perindopril case}

Servier and generic companies appealed against the decision to the GC.48 In its application ${ }^{49}$, Servier claimed, among other things, that the Commission's proceedings were vitiated by a hypothesis-confirmation bias. The Commission, already in the Final Report, found the sector to be 'rotten' and sought at all costs to confirm this view. Further, Servier and the generic companies claimed that the Commission erred in applying Article 101 TFEU. In particular, the companies disagreed with the qualification of settlements as an by 'object' restriction, further they pointed to an error in the assessment of the effects. Servier argued that the Commission did not use a realistic counterfactual scenario since the Servier Decision is based entirely on the ex-ante analysis of hypothetical effects, reproducing its analysis per object.

As regards the infringement of Article 101 TFEU, the GC generally agreed with the Commission that settlements concluded by Servier with the generic companies amounted to anti-competitive agreements, except for the agreement concluded with Krka.

The GC emphasized that side deals may be considered as a value transfer inducing generic companies to abandon its independent efforts to enter the market. This is particularly true if there are temporal or legal links between the side deal and the main patent settlement. However, the GC noted that a licensing agreement concluded between Servier and Krka did not amount to a side deal constituting a value transfer. The GC explained that the Commission failed to prove that the agreement was not entered on market conditions, and in particular that the royalty was abnormally low.

It should also be noted, that the GC struck down the decision of the Commission in the part concerning the abuse of the dominant position since it found that the authority failed to correctly define the relevant market.

The judgments of the GC were appealed by Servier, the Commission and generic companies (except for Krka) to the CJEU. ${ }^{50}$ The CJEU has not issued its judgments yet.

48 All addresses of the Commission's decision in Perindopril case brought appeals to the GC. See GC judgments of 12 December 2018 in cases: T-677/14 Biogaran v. Commission, ECLI:EU:T:2018:910; T-679/14 Teva UK Ltd and Other v. Commission, ECLI:EU:T:2018:919; T-680/14 Lupin Ltd v. Commission, ECLI:EU:T:2018:908; T-682/14 Mylan Laboratories Ltd and Mylan, Inc v. Commission, ECLI:EU:T:2018:907; T-684/14 Krka Tovarna Zdravil d.d. v. Commission, ECLI:EU:T:2018:918; T-701/14 Niche Generics Ltd v. Commission, ECLI:EU:T:2018:921; T-705/14 Unichem Laboratories Ltd v. Commission, ECLI:EU:T:2018:915. See in particular, Case T-691/14 Servier and Others v. Commission ECLI:EU:T:2018:922.

49 Application by Servier brought on 21 December 2014, [2015] OJ C 462/25.

50 See cases: C-201/19 P Servier v. Commission [2019] OJ C139/39; C-176/19 P Commission v. Servier [2019] OJ C139/37, C-166/19 P Unichem Laboratories v. Commission [2019] OJ C148/33; 


\subsection{Critical remarks}

Unsurprisingly, in the Perindopril decision the Commission applied the same test as in the Lundbeck and Fentanyl cases. The analysis differed slightly only in consideration of additional circumstances. Thus, one may have similar doubts about the accuracy of this test when a genuine patent dispute triggers the conclusion of a patent settlement.

The Perindopril decision proves that the criterium of a value transfer needs to be considered functionally, namely as any type of benefit (that is, not only a reverse payment) to a generic company transferred by the originator company. One should agree that this is the correct approach. If an agreement is aimed to restrict competition then any kind of benefit transferred to one of the parties in exchange for the commitment not to enter the market, should be considered as a value transfer. At the same time, finding a value transfer may be sometimes a tricky issue. By a way of example, if a value transfer is comprised in a side deal, then the Commission faces additional difficulty in proving that there was an implicit agreement between the parties that this side deal was actually in exchange for a market entry restriction.

Interestingly, in this case, in comparison to the Lundbeck case, the Commission paid considerably less attention to the patent strength. It clearly indicated that it is not competent to decide on a patent validity and it bases its assessment on the parties' assessment. In relation to the existence of potential competition, given the absence of the parties' documents putting significant doubt on a patent validity, the Commission focuses on the generics' preparation to market entry. As regards the content of the agreement, in contrast to the Lundbeck case, the Commission looks mainly at the size of the payment and the fact that payments were offered in consideration for non-challenge and non-compete obligations.

As regards the analysis of the effects, the counterfactual scenario applied by the Commission seems to be based on a possibility of potential competition. Therefore, it is arguable that it does correspond to the likelihood standard required for proving the anti-competitive effects of the agreements.

Comparing the judgments of the GC in Lundbeck and Perindopril cases, it seems that in the latter the GC relied more on the CJEU's judgment in the $C B$ case and raised the bar for finding an object restriction in relation to PFD agreements. (Buttigieg, 2019, 285). Even though the GC largely agreed with the Commission, it clearly underlined that the burden of proof is on the authority

C-164/19 P Niche Generics v. Commission [2019] OJ C148/31, C-151/19P Commission v. Krka [2019] OJ C148/29, C-197/19 P Mylan Laboratories and Mylan v. Commission [2019] OJ C164/28; C-144/1 9P Lupin v. Commission [2019] OJ C148/24, C-198/19P Teva UK and Others v. Commission [2019] OJ C164/29; C-207/19 P Biogaran v. Commission [2019] OJ C139/40. 
to show that the payment or a side deal constituted an actual incentive to enter into settlements. The GC's assessment of the Servier's settlement with Krka, and finding that it did not restrict competition because of the absence of a clear indication that a licence agreement constituted an anti-competitive incentive, shall also be assessed as raising the bar for finding a restriction by 'object'.

The GC's judgment is also remarkable in terms of the assessment of the effects of the agreement. The GC underlined that when the agreement entered into force, the Commission is obliged to analyse actual and not just potential effects on the market (Killick, Jourdan, Pêcheux, 2019).

\section{Teva Case}

Since April 2011 the Commission has been investigating whether the settlement agreement concluded between Teva and Cephalon may have had the object or effect of restricting competition. The world-wide agreement concluded between the parties concerns modafinil (a Cephalon's pharmaceutical for sleep disorders) and settled litigation in the UK and USA. In July 2017, the Commission sent to Teva a statement of objections. The proceedings are on-going. Commissioner Vestager has recently announced that proceedings are making 'very good progress'. ${ }^{51}$

The case is on-going, thus not much information on the position of the Commission is available. However, one may expect that the Commission will follow the reasoning applied in the cases described above. In the Statement of Objections, the Commission expressed its preliminary view that the contested value transfer induced Teva not to compete with Cephalon worldwide, including EEA. This might have caused a substantial harm to EU patients and health services budgets..$^{52}$

It is too early to draw any conclusions as to the directions of the proceedings. However, if the Commission decided to issue a decision finding a competition infringement, then most likely it would apply the test developed in the earlier case law.

51 M. Vestager, 'Making markets deliver essential medicines, speech at NorWHO, Copenhagen,' 20 August 2018. Retrived from: https://ec.europa.eu/commission/commissioners/ 2014-2019/vestager/announcements/making-markets-deliver-essential-medicines_en

52 European Commission, 'Antitrust: Commission sends Statement of Objections to Teva on 'pay for delay' pharma agreement,' Press release, 17 July 2017. Retrieved from: http://europa. eu/rapid/press-release_IP-17-2063_en.htm 


\section{Summary and concluding critical remarks}

\subsection{Summary of the Commission's and GC's test for the assessment of PFD agreements}

The decisional practice of the Commission proved that patent settlements may have as their object a restriction of competition when: (i) the originator and the generic companies are at least potential competitors; (ii) the settlements include a restriction of the generic's market entry, and a value transfer from the originator company to the generic company; (iii) the value transfer was made in exchange for the generic's obligation to desist from its autonomous efforts to enter the market.

The Commission does not consider the value transfer as per se problematic. However, if the terms of the settlements are not reached on the basis of the strength of the patent, as assessed by the parties, but a generic company is induced by a value transfer to accept them, then the settlements most likely restrict competition. The value of the payment signals the patent strength or weakness. Therefore, the existence of the value transfer and its size point to the competition restrictive object of the settlements.

Inferring the anti-competitive potential of the settlement from the amount of a value transfer is based on a relatively simple economic model based on a trade-off that make both parties to the settlement better-off. The patent settlement has two dimensions: (i) the size of a value transfer, and (ii) the generics' entry date. This simplified model assumes that the greater the value transfer, the more delayed the generics' entry is.

The analysis of the Commission with regard to the effects of patent settlements focuses on the potential competition that would have existed in the absence of the settlement. In particular, the Commission claims that the generic companies would constitute a competitive threat to the originator companies and this might result in either patent invalidation or successful market entry of the generic pharmaceutical. The Commission grounds the probability of the counterfactual scenario in the companies' assessment of the strength of the patent in question. The other factors that the Commission considered were the following: the market power of the parties and the market structure, including the presence of other market players that could potentially challenge the validity of patents in question. 


\subsection{PFD Agreements as a by object restriction - critical review}

The assessment of PFD agreements by the Commission as a by object restriction does not seem to be compatible with the current understanding of this notion in EU competition law. In the $C B$ case, the CJEU recalled that object restrictions should be interpreted restrictively. In particular, these agreements whose object is to restrict competition should be sufficiently deleterious to competition so that there is no need to examine their effects. In this context, considering PFD agreements as per object restrictions seem to be based on the presumption of an inherent anti-competitive effect of these agreements. However, this presumption is not grounded in sound economics but rather it is based on the balance of the probabilities as to patent validity. One may have doubts about whether the alleged harm stemming from PFD agreements is obvious and therefore the by object restriction may not be appropriate (Chowdhury, 2017, p. 379).

The abstract test proposed by the Commission does not enable to identify settlements harmful by their very nature. In particular, the reasoning of the Commission based on equating PFD agreements with market sharing or output limiting agreements is too simplistic, since it ignores the existence of the patent dispute that justifies the conclusion of the settlement.

The Commission suggests that PFD agreements present important parallels to the BIDS case which concerned arrangements aimed at reducing the overcapacity in the Irish beef sector. ${ }^{53}$ The BIDS arrangements envisaged that certain undertakings exit the market (the goers) and the undertakings staying on the market pay the goers financial compensation. The CJEU found that the BIDS arrangements infringed competition law by object. AG Trstenjak described them as the buying-off competition. ${ }^{54}$ The Commission considers that both in BIDS and PFD cases the main focus were exclusion payments.

If one analyses PFD agreements and BIDS arrangements in isolation from their context, indeed, they have some elements in common, namely, the existence of a payment and the restriction on entry. However, drawing analogies between PFD agreements and the BIDS arrangements is unfortunate for several reasons.

The BIDS arrangements restricted actual competition (not a possibility of a potential competition as in PFD agreements $)^{55}$. Furthermore, the BIDS arrangements leave no doubt that they are harmful by their very nature since

53 Lundbeck decision, para. 658, Servier decision paras. 1139-1140.

${ }^{54}$ BIDS case, Opinion by AG para. 77.

55 The Commission defines very broadly the notion of potential competition. In practice, any generic company may be perceived as a potential competitor, unless the impossibility of the market entry is demonstrated. (Killick, 2015, p. 197). Colomo observed that considering 
the worsening of the state of competition as a result of the market exit of the goers is obvious. Thus, pursuant to established case law, the BIDS arrangements were so likely to restrict competition that there was no need to analyse their effects. In addition, the outcome purported by the BIDS arrangements could not be achieved by legitimate means. In contrast, PFD agreements restrict the market entry of generic companies in the circumstances of a patent dispute. As a consequence, there is a certain probability that a restriction could be achieved by means of litigation.

The analysis presented in the BIDS case may be applicable to the co-promotion agreements as in the Fentanyl case with no patent dispute. In both cases the applicable theory of harm is the buying-off of competition. This harm is so likely that there is no need to examine the actual effects of the agreement. This theory of harm cannot be with equal certainty applied to PFD agreements, unless there is indisputable evidence proving the fictitious nature of the patent dispute.

The CJEU in the $C B$ case emphasizes the role of experience in finding the by object restrictions. It was also argued in the literature that it would be prudent to base condemnation of a certain agreement as a by object restriction on sufficient experience or other empirical evidence (Peeperkorn, 2015, p. 44). As regards PFD agreements, the Commission lacks the experience to authoritatively determine that presence of the three main factors (that is potential competition, limitation on generics' entry and value transfer) is sufficient to conclude that a settlement is anti-competitive. This is particularly true given that the economists have widely dispersed views on PFD agreements. Furthermore, numerous uncertainties concerning actual effects of PFD agreements do not enable a claim that these agreements are sufficiently deleterious to competition.

\subsection{PFD Agreements as an effects restriction - critical review}

In its reasoning, the Commission claims that in the absence of the reverse payment, the parties would either conclude a less restrictive settlement or generic companies will continue to challenge the patents held by the originator company. ${ }^{56}$ Therefore, the generic companies most likely would have a chance

\footnotetext{
a generic company to be a potential competitor, because it may successfully enter the market, is tantamount to saying that the Schrodinger's cat is alive because it may be alive (Colomo, 2016).

56 Servier decision, para. 1138. In other words, in the absence of the agreed inducement and, hence, based purely on its assessment of its chances to succeed in the patent dispute, i.e. on the merits of the patent case, the generic company as a reasonable economic operator would not accept the commercial limitations which are accepted in the settlement and instead act independently in keeping with its own specific competitive incentives and resort to more
} 
for an early and independent entry. Thus, the Commission argues that the level of competition (actual or potential) would be higher since the generic companies' incentives to compete would not be distorted by the value transfer. ${ }^{57}$ Furthermore, as argued by the Commission, in the counterfactual scenario, customers would pay less for the pharmaceutical products. ${ }^{58}$

In practice, the analysis of the effects undertaken by the Commission does not differ much from the analysis of the by object restriction, with the only difference being an analysis of the market position of the originator company. However, given that in the Perindopril case, the Commission also found an abuse of a dominance position (which by definition requires analysis of the dominant's market position), one may presume that the analysis of the effects was only supplementary (Jabłonowska, 2014, p. 17).

Generally, the Commission seems to acknowledge that in the absence of PFD agreements, the generic companies would be free either to pursue patent challenges or to insist on less restrictive settlements. As a result, most likely, they will enter the market earlier to the benefit of consumers.

This reasoning seems to be based on a basic model of a patent settlement pursuant to which, settlements should not place consumers in a worse position than they would be in case of litigation. (Shapiro, 2003, p. 396). According to this model, (i) the parties perfectly know the patent strength, or better said, its weakness (and, as a consequence, their expectations as to the litigation outcome are aligned), (ii) the entry date of the generic company is later than the optimal entry due to the reverse payment that exceeds litigation costs. As a result, the consumers are worse off under a settlement with a reverse payment exceeding the litigation costs. This model also implies that absent a reverse payment, the parties would agree on the optimal entry date and therefore these settlements in principle do not raise antitrust concerns.

However, in practice, the real market conditions are far more complex. The patent strength is unknown; furthermore, the expectations as to the litigation outcome and also to future market conditions may significantly differ between the parties. This may generate substantial information asymmetries which will influence the conditions of the settlement. Additionally, risk aversion and potential multiple challenges may affect the final content of the settlement.

The fundamental problem with the counterfactual scenario suggested by the Commission is that there is no certainty that the generic companies would prevail in the litigation. In other words, it may be equally likely that a generic

pro-competitive solutions (for example, continued litigation, acceptance of an early entry settlement).

57 Servier decision, para. 1142.

58 Servier decision, para. 1143. The delay of generic entry resulted in a distinctively higher customer spending on perindopril than in the counterfactual scenario of earlier generic presence. 
company would have won or lost. Whereas the Commission is obliged to show that there were 'real and concrete possibilities' for the parties to the agreement to compete with one another.

There is no doubt that the effects of a certain practice on competition can be potential (in opposition to actual effects that have already materialised on the market). However, potential effects should not be understood as indicating a theoretically possibly impact on competition. It was argued in the literature that the required thresholds for proving anti-competitive effects should be their 'likelihood' (Colomo, Lamadrid, 2017, p. 361-364) Thus the emergence of the anti-competitive effects should be more likely than not.

In the light of the above considerations, it is clear that the counterfactual scenario proposed by the Commission does not correspond to the requirements of the effect analysis, since the Commission does not meet the likelihood threshold. To prove the anti-competitive effects of PFD agreements, the Commission would need to prove that in the absence of the agreement, it was likely that the generic companies would enter the market before the date agreed in the agreement. This entry could occur if the patent was found invalid or not infringed. Thus, the Commission would need to establish any of the two circumstances with more than $50 \%$ likelihood.

In conclusion, the analysis of PFD agreements from the competition law perspective is not satisfactory. Both the object and effect analysis raise doubts as to the compatibility with the principles of competition law.

In particular, a three-step test applied by the Commission for the purpose of determining whether a PFD agreement has as a by object restriction of competition does not allow for stating that these agreements are sufficiently deleterious to competition. Definition of a potential competition is surprisingly broad and incoherent with other types of proceedings. ${ }^{59}$ Equating a buying-off of competition with PFD agreements is too simplistic and does not account for all economic considerations accompanying the conclusion of the settlement. Finally, given that PFD agreements have a legitimate aim (terminating a patent dispute) and may have a pro-competitive effect, one cannot rationally assume that anti-competitive harm is so likely that there is no need to analyse effects of PFD agreements.

59 In particular it was observed in the literature that the standard for determining potential competition differs depending on the type of the proceedings (antitrust or merger control proceedings). In merger control proceedings, the existence of high barriers to entry would prevent deeming a company, whose entry is concretely possible but not likely, as a potential competitor (Ritzmann, 2017). 


\subsection{PFD Agreements - Enforcement by National Competition Authorities}

National case law on pharmaceutical patent settlements has not developed very well yet. So far, only the CMA and the Portuguese competition authority have issued decisions concerning settlements. However, both followed the reasoning developed by the Commission in Lundbeck, Fentanyl and Perindopril cases.

The UK Paroxetine case concerned a settlement concluded by GlaxoSmithKline with generic companies. The CMA largely followed the reasoning applied by the Commission, including finding that these PFD agreements were anti-competitive and formed part of the exclusionary strategy amounting to the abuse of a dominant position. The decision was appealed to the Competition Appeal Tribunal (hereinafter: CAT) which got some doubts about the accuracy of the test used by the CMA and referred to the CJEU for a preliminary ruling. The CAT asked questions on five subjects: (i) potential competition, (ii) restriction by object, (iii) restriction by effect, (iv) market definition and $(\mathrm{v})$ the abuse of a dominant position. ${ }^{60}$

In January 2020, the CJEU decided the case and found that the PFD agreements may restrict competition by object. ${ }^{61}$ In the CJEU's view when a generic company has a firm intention and an inherent ability to enter the market, it may be considered as a potential competitor to an originator company, unless there are insurmountable barriers to entry the market. The presumption of the patent validity, the uncertainty regarding outcome of the dispute and granted injunctions are irrelevant for the purpose of establishing the potential competition. Further the 'object restriction' are only the PFD agreements with regard to which there are no proven procompetitive effects capable of giving rise to a reasonable doubt that they cause a sufficient degree of harm to competition. The CJEU also rejected that the relevant counterfactual in the assessment of the effects is possibility to win the litigation or to conclude less restrictive settlement. According to the CJEU, the relevant counterfactual is the originator company's conduct in the absence of the PFD agreement.

The CMA continues its enforcement in this area. In March 2017, it issued a statement of objections addressed to Actavis and Concordia in relation to the agreement allegedly incentivising the latter not to enter the market. The case is pending. ${ }^{62}$

${ }^{60}$ CAT, Order for Reference for a Preliminary Ruling, Case Nos: 1251-1255/1/12/16, 27 March 2017.

61 CJEU judgment of 30 January 2020, Case C-307/18 Generics (UK) Ltd and Others

v. Competition and Markets Authority, ECLI:EU:C:2020:52.

62 https://www.gov.uk/cma-cases/pharmaceutical-sector-anti-competitive-agreements 
The Portuguese Competition Authority analysed the agreement between Astra Zeneca, on the one hand, and Teva and its subsidiary Ratiopharm, on the other hand, concerning the sale of rosuvastatin generic product. ${ }^{63}$ The parties settled a patent dispute that emerged at the time when rosuvastatin compound was protected by the supplementary protection certificate (SPC) obtained by Astra Zeneca. Teva obliged not to market its generic product until the date of the SPC's expiration, whereas AstraZeneca agreed to withdraw and discontinue its actions against Teva in Portugal. The settlement did not include any form of value transfer as well, as it was a full and final settlement of the dispute.

The Portuguese Competition Authority in its analysis largely followed principles established by the Commission. It did not find a competition law infringement since the settlement did not include a value transfer and the obligation not to enter the market did not exceed the scope of the exclusionary right.

\subsection{PFD agreements - further developments?}

Given the deficiencies identified in the approach of the Commission, views of the CJEU on PFD Agreements were much awaited. The CJEU's judgment in Paroxetine case will probably set the precedent for cases pending before this court in Lundbeck and Servier cases. It shall be positively assessed that the CJEU confirmed narrow understanding of the object restrictions and indicated that the net effect of the PFD agreement shall be decisive for its recognition as a hardcore restriction. Regrettably, patent validity and uncertainty as to the outcome of the dispute were exclude by the CJEU from the scope of considerations. Moreover, the CJEU's thoughts on the relevant counterfactual are rather vague and more certainty in this area will be needed.

Further, if the Commission or national authorities decide to pursue further cases on the PFD agreements one may expect that other variations of the value transfer will be considered (Lawrance, Bond, 2018, p. 2). Already the Servier case proved that a value transfer may go beyond paying a generic company a lump sum of money. The U.S. case law on patent settlements further demonstrate that the value transfer may take a very sophisticated form. By way of example, the settlements concluded in the U.S. included an originator company's commitment not to market its own or an authorised, generic version of the reference medicinal products (so-called no-AG agreements). It was argued that a no-AG agreement serves as a second non-compete arrangement. The harm stems not only from the fact that a generic company refrains from challenging a patent but also from the impact on prices resulting from the absence of the AG on the market.

63 Decision of the Autoridade da Concorrencia dated 29 March 2016, no PRC/2014/4. (hereinafter: AdC Decision). 


\section{Literature}

Barazza, S. (2014). Pay-For-Delay Agreements in the Pharmaceutical Sector: Towards coherent EU approach. European Journal of Risk Regulation 5(1), 79-86; https://doi. org/10.1017/s1867299x00002993

Bucknell, D. (2011). Pharmaceutical, Biotechnology and Chemical Inventions. World Protection and Exploitation Volume II. Oxford: Oxford University Press.

Buttigieg, E. (2019). The Servier Judgments - the GC's Evolving Case Law on Pay-ForDelay Patent Settlements, Journal of Antitrust Enforcement 7, 279-289.

Choi, W., Uyl, B., Hughes, M. (2014). Pay-For-Delay Practices in the Pharmaceutical Sector: Lundbeck, Actavis, and Others. Journal of European Competition Law and Practice, 5(1), 44-52; https://doi.org/10.1093/jeclap/lpt071

Chowdhury, A. (2017). The notion of restriction of competition: economic prospect. In D. Gerard, M. Merola, B. Meyring (Eds). The Notion of Restriction of Competition. Brussels, Bruylant.

Colomo, P. (2016). GC Judgment in Case T-472/13, Lundbeck v Commission: on patents and Schrödinger's cat, Chillin'Competition 13 September 2016, https://chillingcompetition. com/2016/09/13/gc-judgment-in-case-t-47213-lundbeck-v-commission-on-patents-andschrodingers-cat/

Colomo, P., Lamadrid, A. (2017). Restriction of Competition of Competition What We Know and What We Don't Know We Know. In D. Gerard, M. Merola, B. Meyring (Eds) The Notion of Restriction of Competition. Brussels, Bruylant.

Elhauge, E., Krüger, A. (2012). Solving the Patent Settlement Puzzle. Texas Law Review, 91, 283-330.

Friend, M. (2017). Reverse Patent Settlements and EU Competition Law. The Cambridge Law Journal 76, 1, 29-32; https://doi.org/10.1017/s0008197317000216

Gallasch, S. (2016). Activating Actavis in Europe - the Proposal of a 'Structured EffectsBased' Analysis for Pay-For-Delay Settlements. Legal Studies 36, 4, 683-705; https:// doi.org/10.1111/lest.12130

Geradin, D., Ginsburg, D.H. and Safty, G. (2015). Reverse Payment Patent Settlements in the European Union and the United States. George Mason University Legal Studies Research Paper Series, 1-24.

Gratz, L. (2012). Economic Analysis of Pay-for-delay Settlements and Their Legal Ruling. Munich Discussion Paper 2012-6, University of Munich, Department of Economics, $1-36$.

Hovenkamp, E. (2018). Antitrust Law and Patent Settlement Design, http://dx.doi. org/10.2139/ssrn.3219954.

Hull, D.W., Clancy, M.J. (2017). The Application of EU Competition Law in the Pharmaceutical Sector. Journal of European Competition Law and Practice 8, 3, 205-218.

Hull, D.W., Clancy, M.J. (2018). The Application of EU Competition Law in the Pharmaceutical Sector. Journal of European Competition Law and Practice 9, no. 6, 389-402.

Jabłonowska, A. (2015). Ugody patentowe zawierane w sektorze farmaceutycznym w świetle prawa konkurencji Unii Europejskiej. Europejski Przegląd Sądowy, 8, 12-17. 
Kerber, W. and Frank, S. (2016). Patent Settlements in the Pharmaceutical Industry: What Can We Learn from the Economic Analysis? MAGKS Joint Discussion Paper Series in Economics 01, 1-21. https://dx.doi.org/10.2139/ssrn.2773543

Killick, J. (2015). Patent Settlement as by Object Restrictions: a European Approach but Is It the Right One? In D. Edward, J. MacLennan, A. Komninos (Eds), Ian S. Forrester A Scot without Borders Liber Amicorum Volume II. Paris: Concurrences Review.

Killick, J., Jourdan, J. and Pêcheux, P. (2019). The Servier Judgment: The General Court Annuls the Commission's Market Definition but Confirms the Illegality of Certain Patent Settlement Agreements, Journal of European Competition Law \& Practice 10, 1, 25-30; ttps://doi.org/10.1093/jeclap/lpz005

Kolasiński, M.K. (2017). Ugody patentowe o odwróconej płatności jako porozumienia o antykonkurencyjnym celu. Przeglad Prawa Handlowego, 7, 17-22.

Lawrance, S. and Bond, E. (2018). 'Reverse Payment' Patent Settlement Agreements: Non-Cash Value Transfer is Not Immune from Competition Law Scrutiny. Journal of Intellectual Property Law and Practice 13, 7, 552-554; https://doi.org/10.1093/jiplp/jpx230

Lawrance, S., Rotondo, E., Treacy, P. (2016). IP and Competition: A Survey of Developments, Journal of European Competition Law and Practice 7, 3, 227-240; https:// doi.org/10.1093/jeclap/lpv084

Murphy, M. (2008). Red Flag or Red Herring: Reverse Payments and the Settlement of Pharmaceutical Patent Litigation. European Competition Journal 4, 2, 541-560; https:// doi.org/10.5235/ecj.v4n2.541

Pais, S. (2017). The Lundbeck Case and the Concept of Potential Competition. In (Eds)

K. Fournier, D. Ritzmann, S.M. Colino, S. Païs, N. Dunne, Concurrences Review 2.

Peeperkorn, L. (2015). Defining "By Object" Restrictions. Concurrences 3, 40-50.

Regibeau, P. (2013). 'Pay for Delay' What We Disagree on? Competition Policy International 9 , no. 2.

Ritzmann, D. (2017). The Lundbeck Case and The Concept of Potential Competition. In K. Fournier, D. Ritzmann, S. Marco Colino, S. Païs, N. Dunne (Eds), The Lundbeck case and the concept of potential competition. Concurrences Review 2.

Schröder, V. (2016). Pay-for-Delay Settlements in the European Union - Did the Commission Go Too Far? European Competition Law Review 12, 506-512.

Shapiro, C. (2003). Antitrust Limits to Patent Settlements. RAND Journal of Economics 34, 2, 391-411.

Ska, N., Werner, P. and Paul, Ch. (2017). Pay-for-delay Agreements: Why the EU Should Judge them by their Effects. Journal of European Competition Law and Practice 8, no. 7, 437-450; https://doi.org/10.1093/jeclap/lpx029

Straus, J. (2016). Pay for Delay - A Subtly Hidden, Overlooked or Ignored Transatlantic Divide: Exemplified on the Actavis Decision of the US Supreme Court and the Servier Decision of the EU Commission. Zbornik znanstvenih razprav 76, 197-234.

Subiotto, R. and Figus Diaz, J. (2017). Lundbeck v Commission: Reverse Payment Patent Settlements as Restrictions of Competition by Object. Journal of European Competition Law and Practice 8, 1, 27-29; https://doi.org/10.1093/jeclap/lpw093

Szczepanowska-Kozłowska, K. (2015). Wyłączność korzystania z praw własności przemysłowej. In E Nowińska, and K. Szczepanowska-Kozłowska (Eds), Prawo Wtasności Przemystowej System Prawa Handlowego Tom 3. 
Treacy, P., Lawrance, S. (2011). Intellectual Property Rights and Out of Court Settlements. In S. Anderman, and A. Ezrachi (Eds). Intellectual Property and Competition Law. New Frontiers.

Woodcock, R. (2017). Innovation and Reverse Payments. Florida State University Law Review 44, 774-818.

Woude, M. (Autumn 2009). Patent Settlements and Reverse Payments Under EU Law. Competition Policy International 5, 2, 183-196.

Zafar, O. (2014). Lundbeck, and Johnson \& Johnson and Novartis: The European Commission's 2013 'pay-for-delay' decisions. Journal of European Competition Law and Practice 5, 4, 207-210; https://doi.org/10.1093/jeclap/lpu023 